\title{
高効率な微細金型ポリシング加工技術の開発*
}

田辺 郁男 ${ }^{*}$, 安藤 泰士 ${ }^{* 2}$, 高橋 智*2

\section{Development of Polishing with High Efficiency on Small Mold and Die}

\author{
Ikuo TANABE $^{* 1}$, Taishi ANDO and Satoshi TAKAHASHI \\ *1 Nagaoka University of Technology. Dept. of Mechanical Engineering \\ 1603-1Kamitomioka-machi, Nagaoka, Nigata, 940-2188 Japan
}

Recently, mirror-like surface on a mold and a die was required for adding high quality on the most products. Particularly, as the processing of the mirror-like surface on the mold or the die with small and complex shape is difficult, the processing is performed a very long time by polishing of the skilled worker. Automatic polishing for the products is very difficult. Therefore the polishing with high efficiency on a small mold or die with complex shape was developed and evaluated. The three polishing tools were firstly developed for the experiment; the first polishing tool is the tool for the high speed polishing on the area in the die, the second tool is the tool using a contour line for the middle speed polishing on the line in the die and the third tool is the tool using a small ball (less than $1 \mathrm{~mm}$ diameter) for polishing on the point in the die with small and complex shape. The optimum tool for each size or shape in a die and its optimum polishing condition are investigated for high efficiency in several experiments. The polishing tool is installed in the spindle of the CNC milling machine. This system was evaluated for high speed polishing the mirror-like surface on the small parts with complex shape. It is concluded from the results that the three tools and its polishing process were effective for processing the mirror-like on the surface of the small parts with complex shape, and optimum polishing condition was also cleared.

Key Words : Polishing, Mold, Die, Mirror-Like Surface, Small Part, Complex Shape

\section{1. 緒言}

工業製品の高品位化のため，金型の鏡面加工はきわめて重要な作業になっている．しかし，この作業は現在で も熟練作業者による長時間のポリシング加工 ${ }^{(1)}$ が主流であり，それが生産性の低減や開発の遅れを生じる原因と なっている. そのため, 迅速に鏡面加工を行うための技術が要求されている. そこで, これまでの研究において, ポリシングニニットを複数個集合化させたポリシング工具端子を開発し，大型部品を自動ポリシング加工するシ ステムを開発した ${ }^{(2)}$. また，小型リニアモータ駆動を用いて，数ミリ程度の小部品への高速自動ポリシング加工 技術の開発(3)や，ポリシング工具端子を温度管理し，プラスチックのような軟質材料の鏡面ポリシング加工技術 の開発 ${ }^{(4)}$ も行った. さらに，複雑形状を有する微細部品の鏡面加工のための技術開発 ${ }^{(5)} も$ 行った. また，その間， $\mathrm{EPD}^{(6),(7)}$ 砥石や MAGIC 砥石 ${ }^{(8)}$ などの高機能な砥石も開発されている. とくに, 現在, 複雑形状・微細部品の鏡面加工 は付加価值のきわめて高い加工技術であるが，加工時間が長く，さらなる高効率化が必要であった.

そこで本研究では，複雑形状の微細部品を効率良く鏡面加工するために，ポリシング工具とそれを使用したポ リシング加工技術を開発した。具体的には，低効率ながら複雑微細部分にも適用できる点ポリシング工具，中間 効率の線ポリシング工具, 高効率加工が可能な面ポリシング工具をそれぞれ開発した. 次に, 各工具の最適加工 条件を検討し, 加工効率や工具寿命を比較して寸法精度と形状精度に配慮した表面粗さ改善方法の確立を行った。 最後に，製作したポリシング工具を用いて，複雑形状を有する超硬製微細金型の鏡面ポリシング加工を行い，本 システムの評価を行った.

\footnotetext{
*原稿受付 2012 年 10 月 13 日

*1 正員, 長岡技術科学大学 (

*2 長岡技術科学大学

E-mail: tanabe@mech.nagaokaut.ac.jp
} 


\section{2. ポリシングエ具の開発とそれを用いたポリシング加工技術の確立}

\section{$2 \cdot 1$ 本ポリシングの原理および加エ方法}

図 1 に本報で使用しているポリシング加工の原理を示す．エポキシ樹脂のような軟らかい工具端子と，超硬合 金のような硬い工作物とが接触するとき，両者に挟まれたダイヤモンド砥粒は軟らかい工具端子の方へ深く刺さ る.ダイヤモンド砥粒の工具端子への押し込み深さは各砥粒の大きさや形状でまちまちになるが，それによって 硬い工作物への押し込み深さは均一化する. また，工作物と工具端子との硬さ比が大きくなるにつれて，この均 一化の傾向は大きくなる．次に，この工具端子が砥粒を保持したまま水平方向に移動すれば，工作物には均一に 押し込まれたダイヤモンド砥粒によって引っかき傷がつけられる。この傷の深さが $0.1 \mu \mathrm{m}$ 以下になれば，結果的 に鏡面が得られることになる，以上の原理により，きわめて単純・安価なシステムであるにもかかわらず，複雑 形状を有する微細金型の自動鏡面加工が容易に可能となる.

図 2 に 4 種類のポリシング工具を示す．ポリシング工具の形状と工作物へのアプローチの仕方によって，接触 形態は点接触，線接触，面接触の 3 つに大別できる，なお，点接触および線接触に関しては，厳密には面での接 触になるが，本論文内ではこれらを単に点接触および線接触と呼ぶことにする.

各工具の加工効率は，一般的に点＜線＜面の序列を付けることができる. また，複雑形状への適応性は，面＜ 線<点の順で向上し，効率とは逆の序列を付けることができる．加工時間の序列もそれに等しく，面＜線<点の 順で長くなる. そのため, 図 2 に示すように, 高効率加工を可能にするための面ポリシング工具 2 種, 効率は中 間的ながら面ポリシング加工が困難な場所で使用する線ポリシング工具, 低効率ながら面ポリシング加工や線ポ リシング加工が困難な複雑・微細部分の加工で使用する点ポリシング工具の全 4 種類のポリシング工具を開発し た.すべてのポリシング工具において送り動作と位置決めは NC 制御で行うが，主軸を回転させる工具と回転さ せない工具がある。

When the soft tool presses on the hard workpiece, differences between depths of several diamond grains in the workpiece become uniformly.

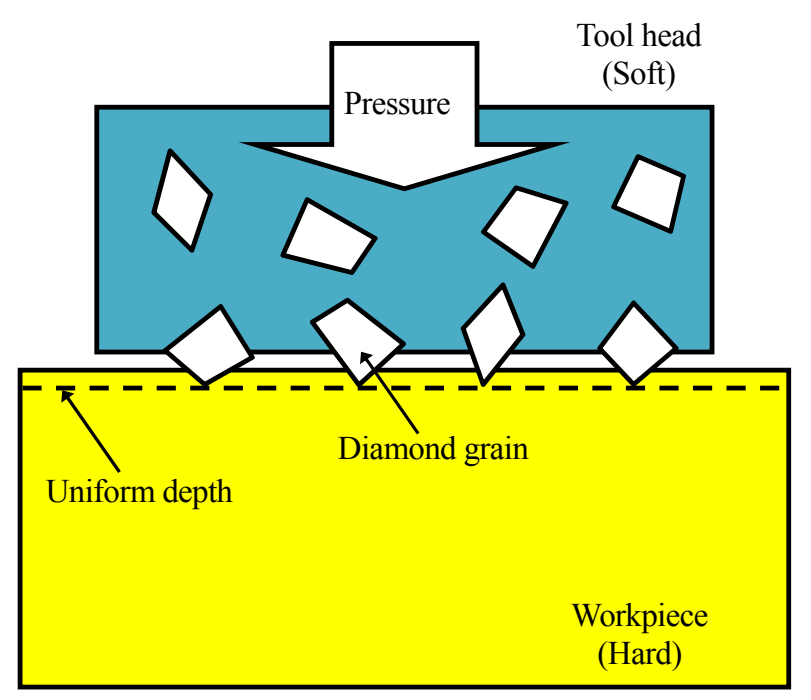

Fig.1 Polishing principle

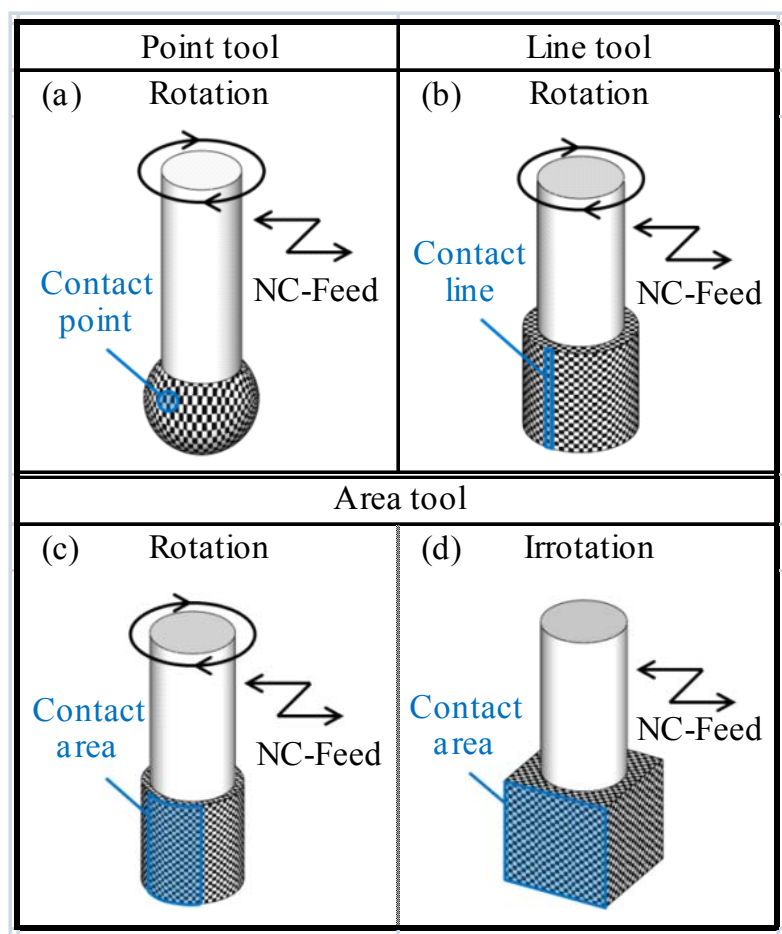

Fig.2 Schematic view of four polishing tools for fast polishing

困 3 に本ポリシングシステムを示す. 使用するポリシング工具は, 図 2 に示すようにステンレス製のパイプや 棒材の端にダイヤモンド砥粒を含有したエポキシ樹脂製端子を配したものである.これらの工具を，小型コレッ トチャックやドリルチャックを用いて工作機械の主軸に取り付ける. また, テーブル上の容器に工作物を固定し, 容器内はダイヤモンド砥粒を混入したラップ剂で満たしておく，その際，砥粒が沈まないようラップ剂にポリマ 
(PEO : Poly-ethylene-oxide) を混入しておくことで，均一な砥粒分布を長時間維持可能になるとともに，ラップ 剤が非ニュートン流体化し, 動くものに追従する特性が付加される(6). この特性により, 図 3 の拡大部に示すよ うに，ポリシング工具を回転させながら工作物に押し当てたときに，ラップ阂中のダイヤモンド砥粒は加工部に 吸い寄せられ，ポリシング工具表面上のダイヤモンド砥粒とともにポリシング加工に寄与する.

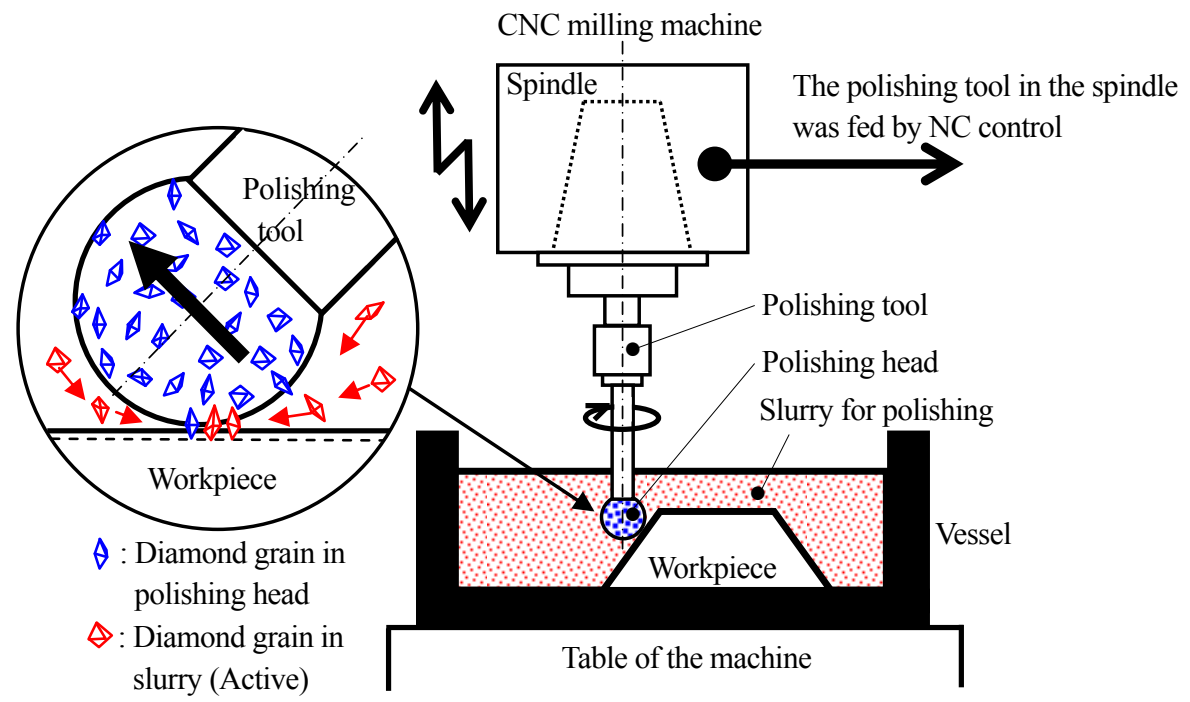

Fig.3 Schematic view of polishing system

本システムを用いてポリシング加工を行う際には，その前加工の NC プログラムを流用することができる．例 えば前加工が切削であった場合, その NC プログラムを編集し, 座標のオフセット值や加工ピッチを用いてポリ シング工具端子の仕様に合わせて調整することで, ポリシング加工用の NC プログラムとして使えるようになる. また, 前加工が型彫り放電加工であった場合にも，その電極製作のための NC プログラムを流用することが可能 である.

\section{$2 \cdot 2$ 新しいポリシングエ具の製作方法および仕様}

本研究で使用する各ポリシング工具の製作方法を，図 4 を用いて説明する.

図 4 (a)は，注射器を用いて球状ポリシング工具を製作する方法を示している．図2(a)はこの製法を使用する. (1)表 1 に示す 2 液混合型のエポキシ樹脂にダイヤモンド砥粒を入れ，よく混ぜる. (2)先端が平らな注射針を用い て, (1)のエポキシ樹脂を吸い上げる. (3)そのまま注射器を恒温器に格納し, $45^{\circ} \mathrm{C} て ゙ 50$ 分間養生させると, エポキ シ樹脂が硬化反応を起こし, 樹脂の粘度が増加する. (4)恒温器から取り出した注射器に微小量の押し込みを与え, 注射針の先端にエポキシ樹脂の球を形成する. (5)エポキシ樹脂の完全硬化後, 針を注射器から切り離すことで, 球状端子を有するポリシング工具が完成する.

図 4 (b)は, プラスチック粘土の型を用いて任意形状のポリシング工具を製作寸る方法を示している. 図 2(b), (d) はこの製法を使用する．熱軟化させたプラスチック粘土に任意形状の物体を押し付けて型を取り，その後冷却し

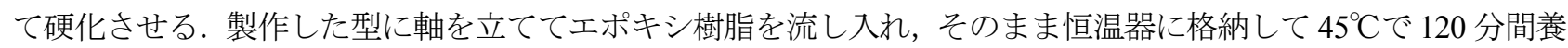
生させる. エポキシ樹脂の完全硬化後に離型すれば, 任意形状の端子を有するポリシング工具が完成する. なお, エポキシが軸から剥離するのを防ぐため，サンドペーパーで軸の表面を粗くしておく．

図 4 (c)は，エポキシ樹脂の摩耗を利用して，工作物の加工部と同じ形状を有する工具端子を製作する方法を示 している．最初に図４(a),(b)などの方法を用いて元となる工具を製作しておく. 次に, 本ポリシングの加工対象 となる部分に工具を押し当てて摩擦熱を発生させ，工作物の前加工形状を工具端子に転写して成形する．この製 法はきわめて容易・迅速な面ポリシング工具の製作を可能とし，さらに，ポリシング工具の高精度な回転中心を 得ることができ，工作物一工具間の高精度な位置決めも可能となる. 点ポリシング工具以外のあらゆる工具につ いて，この製法の利用が効果的であり，とくに複雑な形状を有する工作物に対してきわめて有効である. 
The bolt is turned before hardening of epoxy resin

(1)

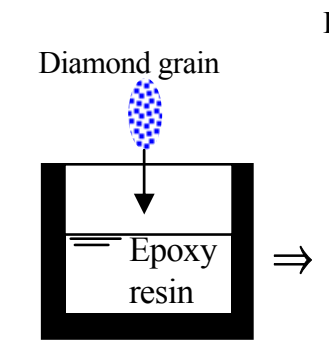

Diamond grain drops into epoxy resin

Epoxy resin drops into the private die with the shaft

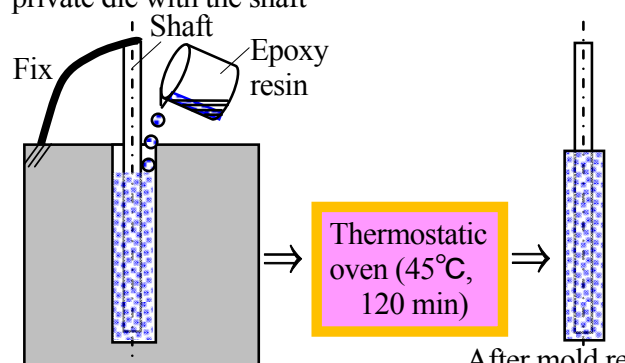

After mold releasing

(b) Manufacturing of the polishing tool using the private die
Hypodermic syringe

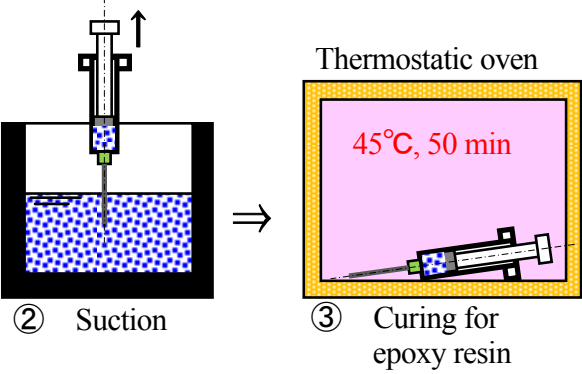

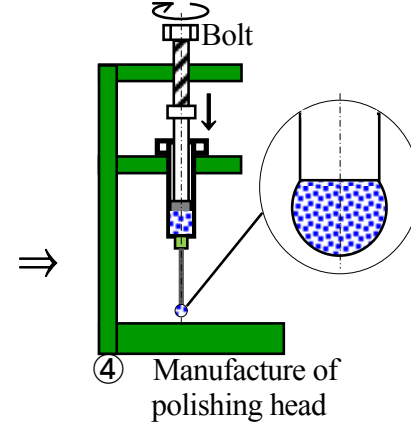

Manufacture of
polishing head

(a) Manufacturing of point tool by using a hypodermic syringe

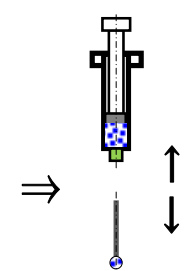

(5) Needle is cut after hardening of epoxy resin

Fig. 4 Procedure of tool manufacturing

Table 1 Specification and accuracy of the tools

\begin{tabular}{|c|c|c|c|c|}
\hline \multirow{2}{*}{ System } & Point tool & Line tool & \multicolumn{2}{|c|}{ Area tool } \\
\cline { 2 - 5 } & Rotational & Rotational & Rotational & Irrotational \\
\hline \multirow{4}{*}{ Picture and size } & & & \\
& & & \\
& & & \\
& & & \\
& & & \\
\hline
\end{tabular}

表 1 に，使用したエポキシとダイヤモンド砥粒，製作したポリシング工具の仕様と精度をそれぞれ示す.

点ポリシング工具については, 直径 $0.4,0.5,0.6,0.7 \mathrm{~mm} の 4$ 種類の注射針を使用して, 直径 $0.43 \mathrm{~mm}$ から 1.13 $\mathrm{mm}$ までの球状端子を有するポリシング工具を製作した(図 4(a)).この球状端子の真球度の平均は $7 \mu \mathrm{m}$ から $12 \mu \mathrm{m}$ 程度であった．なお，球径のコントロールは押し込み量の調節で容易に可能であった．硬化剤の種類によってエ ポキシ樹脂の粘性は大きく異なるため, 今回使用したもの（表 1）とは粘性の異なるエポキシ樹脂を用いたり， 直径の異なる注射針を用いたりすることで，さまざまな径の工具を製作することができる. 
線ポリシング工具については, 直径 $1.5 \mathrm{~mm}$ のピアノ線を軸に使用して, 直径 $2 \mathrm{~mm}$, 高さ $2 \mathrm{~mm}$ の円柱状端子を 有するポリシング工具を製作した（図 4(b))．円柱の真円度の平均は $4 \mu \mathrm{m}$ から $9 \mu \mathrm{m}$ 程度であった.

面ポリシング工具については，回転させる工具と回転させない工具の 2 種類を製作した．前者は，ラップ剂を 使用せずに円柱状ポリシング工具を直接工作物に押し付けて摩耗させることで，工作物の形状を転写したポリシ ング工具を製作した（図 4(c))．後者については，直径 $1.5 \mathrm{~mm}$ のピアノ線を軸に使用して，角に R0.4を有する各 辺 $2 \mathrm{~mm}$ の角柱状端子を有するポリシング工具を製作した（図 4(b)).

\section{3. 最適加工条件の選定}

\section{$3 \cdot 1$ 各ポリシングエ具の選択}

点, 線, 面の各ポリシング工具の選択方法として, 加工が可能であること, 得られる表面粗さが所望值を満足 寸ること， NC 制御で所望の動作ができること，加工時間が短時間であることの 4 つを挙げることができる． 4 種類のポリシング工具の加工時間は，一般的に面＜線<点の順で長くなるため，使用する工具の選択方法は，(1) 面ポリシング工具で加工可能かどうかを検討する．可能な場合には，それで得られる表面粗さが所望值を満足す るかどうかを検討し，満足しない場合には面ポリシング工具の使用をあきらめ，別のポリシング工具の使用を検 討寸る. (2)面ポリシング工具での加工が不可能で，線ポリシング工具での加工が可能な場合には，それで得られ る表面粗さが所望值を満足するかどうかを検討し，満足しない場合には線ポリシング工具の使用をあきらめ，点 ポリシング工具の使用を検討することになる.

\section{$3 \cdot 2$ 各ポリシングエ具の最適加工条件}

ここでは, 各ポリシング工具の最適加工条件を実験によって明らかにする. 表 2 に最適ポリシング加工条件を 評価するための実験条件を示す.対象とする工作物材料は, 金型材料としてよく使用されている超硬V10とした.

Table 2 Polishing conditions for evaluating optimum conditions

\begin{tabular}{|c|c|c|c|c|c|}
\hline \multirow{2}{*}{\multicolumn{2}{|c|}{ System }} & Point tool & Line tool & \multicolumn{2}{|c|}{ Area tool } \\
\hline & & Rotational & Rotational & Rotational & Irrotational \\
\hline \multirow{3}{*}{\multicolumn{2}{|c|}{ Rotating speed $\quad \min ^{-1}$}} & 8000 & 6000 & 6000 & \\
\hline & & 9000 & 8000 & 8000 & \\
\hline & & 10000 & 10000 & 10000 & \\
\hline \multirow{3}{*}{\multicolumn{2}{|c|}{ Feeding speed $\quad \mathrm{mm} / \mathrm{min}$}} & 1.0 & 0.5 & 0.5 & 1000 \\
\hline & & 2.0 & 1.0 & 1.0 & 2000 \\
\hline & & 4.0 & 2.0 & 2.0 & 3600 \\
\hline \multirow{3}{*}{\multicolumn{2}{|c|}{ Polishing pressure $\mathrm{MPa}$}} & 80 & 50 & 1 & 10 \\
\hline & & 100 & 60 & 2 & 20 \\
\hline & & 120 & 70 & 3 & 30 \\
\hline \multirow{3}{*}{\multicolumn{2}{|c|}{$\begin{array}{l}\text { Number of process } \\
\text { ( Number of times of the tool } \\
\quad \text { passing the same point ) }\end{array}$}} & 1.67 & \multirow{3}{*}{2.50} & \multirow{3}{*}{1.00} & 10000 \\
\hline & & 2.50 & & & 15000 \\
\hline & & 3.33 & & & 20000 \\
\hline \multirow{2}{*}{\multicolumn{2}{|c|}{ Polishing condition }} & $\phi 0.7$ & $\phi 1.5$ & $\phi 1.5$ & $\phi 1.5$ \\
\hline & & & & $\phi 1.8$ & \\
\hline \multirow{3}{*}{ Slurry } & Base & \multicolumn{4}{|c|}{ "Water } \\
\hline & Diamond grain & \multicolumn{4}{|c|}{ Mesh size : \#5000, 10wt $\%$ for water } \\
\hline & PEO & \multicolumn{4}{|c|}{$1 \mathrm{wt} \%$ for water } \\
\hline \multicolumn{2}{|c|}{ Workpiece } & \multicolumn{4}{|c|}{ "Carbide (V10), Surface roughness Rz $8 \mu \mathrm{m}$} \\
\hline
\end{tabular}


対象とする加工領域は，平面部は $2 \mathrm{~mm} \times 2 \mathrm{~mm}$ で $4 \mathrm{~mm}^{2}$ の領域を，曲面部は 4 分の 1 円弧（R0.9）を高さ $4 \mathrm{~mm}$ まで約 $5.65 \mathrm{~mm}^{2}$ の領域を加工することとした. 加工には，表 1 に示した 4 種類の工具を用い，ポリシング工具と

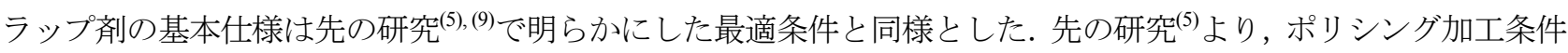
は, 主軸回転数, 送り速度, ポリシング圧力, 工具が加工領域上のある 1 点を通過する平均回数（工程数）の 4 つが重要であることが明らかである。ここで工程数とは，オーバーラップ率や加工ピッチに等しいパラメータで あり, 工程数が 1 回を下回ると削り残しが発生する.また，主軸回転数とポリシング工具の直径は周速度に直接 関係する值であり，使用する工具が変わったときにはその直径に反比例した主軸回転数を設定することで，同じ 周速度でのポリシング加工が可能になる.

また，最適ポリシング加工条件を決定する際に，その結果に高いロバスト性をもたせるために品質工学 ${ }^{(10)}$ を使 用した. 表 2 の主軸回転数, 送り速度, ポリシング圧力, 工程数の 4 つを制御因子, 測定位置 3 箇所（上部，中 央部，下部）を誤差因子，表面粗さ Rz（最大高さ）（測定仕様 : 測定長さ $129 \mu \mathrm{m}$ ，分解能 $0.01 \mu \mathrm{m}$ ，カットオフな し. 以後のすべての表面粗さの測定はこの測定仕様を使用）を最終機能（目標值）とし，静特性で計算した.

図 5 は 4 種類のポリシング工具（表 1 参照）のうち, 点ポリシング工具の SN 比と感度の要因効果図を一例と して示した. SN 比が大きいことはバラつきが小さいこと，感度が小さいことは仕上げ面の表面粗さが小さいこ とを示している.この結果より, 点ポリシング工具の最適加工条件は, 主軸回転数 $10000 \mathrm{~min}^{-1}$, 送り速度 $2.0 \mathrm{~mm} / \mathrm{min}$, ポリシング圧力 $80 \mathrm{MPa}$ ，工程数 2.5 回（オーバーラップ率 $60 \%$ ） と決定した. ここでは省略するが，まったく同 様の方法で, 他の 3 種類（線ポリシング工具 1 種類, 面ポリシング工具 2 種類）の最適加工条件も決定した.

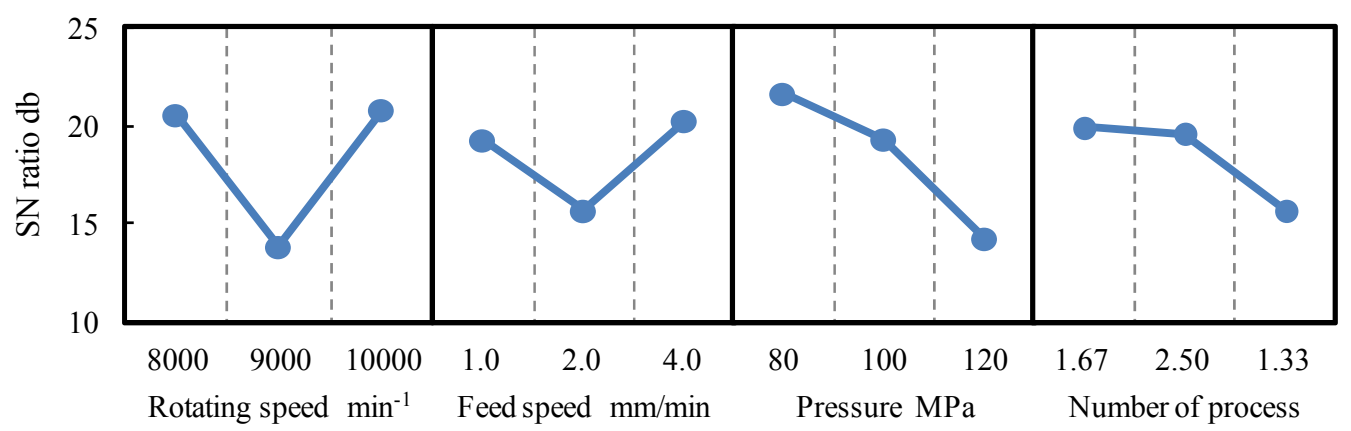

(a) $\mathrm{SN}$ ratio of surface roughness after polishing

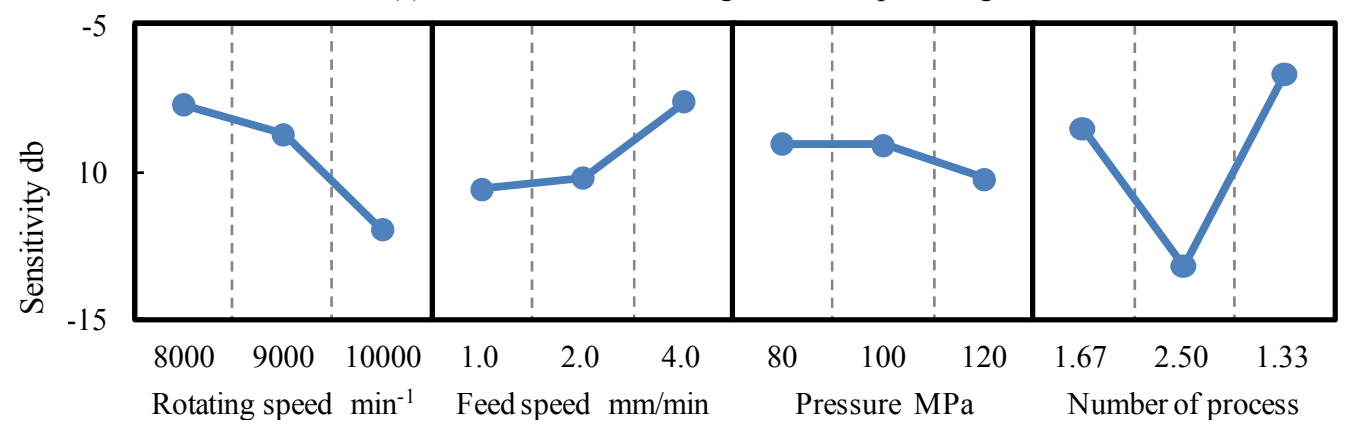

(b) Sensitivity of surface roughness after polishing

Fig.5 SN ratio and Sensitivity of point tool

表 3 に示すように，品質工学を用いた実験を行うことで，各ポリシング工具に対応した最適なポリシング加工 条件を決定した．工作物や工具の大きさ，形状が異なる場合にも，上記と同様の実験を行うことで対応が可能で ある.これ以後, 本報の実験はこの最適ポリシング加工条件を用いて行うこととする. 表 3 中には加工特性（ポ リシング速度と最終的な表面粗さ）も示してある.これを考慮して $3 \cdot 1$ 節の各ポリシング工具の選択を遂行する ことにより，効果的なポリシングが可能になる．このポリシング速度は，工具と工作物との接触面積によって大 きく変わる值であり，これが表 1 に示す 4 種類のポリシング工具の大きな特徴でもある. 生産管理のためには, 使用する工具ごとにこの加工特性を把握しておくことが必要である. また，今回は 1 方向であった送りを複数方 向から与えることで，表面粗さを更に改善することができるが(2),(3)，本研究ではそれは行わない. 
Table 3 Optimum conditions for polishing

\begin{tabular}{|c|c|c|c|c|c|c|}
\hline \multirow{2}{*}{\multicolumn{3}{|c|}{ System }} & \multirow{2}{*}{$\begin{array}{l}\text { Point tool } \\
\text { Rotational }\end{array}$} & \multirow{2}{*}{$\begin{array}{c}\text { Line tool } \\
\text { Rotational }\end{array}$} & \multicolumn{2}{|c|}{ Area tool } \\
\hline & & & & & Rotational & Irrotational \\
\hline \multirow{4}{*}{$\begin{array}{l}\text { Polishing } \\
\text { condition }\end{array}$} & Rotating speed & $\min ^{-1}$ & 10000 & 8000 & 8000 & - \\
\hline & Feeding speed & $\mathrm{mm} / \mathrm{min}$ & 2.0 & 2.0 & 0.5 & 2000 \\
\hline & Polishing pressure & $\mathrm{MPa}$ & 80 & 50 & 3 & 30 \\
\hline & Number of process & & 2.5 & 2.5 & 1.0 & 15000 \\
\hline \multirow{2}{*}{$\begin{array}{l}\text { Polishing } \\
\text { efficiency }\end{array}$} & Polishing speed & $\mathrm{min} / \mathrm{mm}^{2}$ & 25.0 & 2.0 & 0.7 & 6.0 \\
\hline & Surface roughness & $\mathrm{Rz} \mu \mathrm{m}$ & 0.15 & 0.11 & 0.14 & 0.09 \\
\hline
\end{tabular}

\section{$3 \cdot 3$ 表面粗さの改善にともなう寸法の変化}

図 6 にポリシング加工時間に対する表面粗さ（Rz）およびポリシング量の変化を示す．ポリシング量は工作物 の深さ方向の減少量で，これが大きくなるとポリシングのしすぎによる寸法精度と形状精度の低下に注意が必要 である．長時間にわたり加工を続けることで表面粗さは頭打ちとなり，ポリシング量だけが増加している.

図 7 にポリシング加工時間に対するポリシング工具の体積変化（摩耗の程度）示す。このように工具端子が摩 耗することで，接触面積や圧力が変化してしまう。これらによる加工精度（表面粗さ，寸法精度，形状精度）の 低下を防ぐために，各工具の適切な交換時期を設定することが重要である．また，ポリシング加工後の寸法精度 と形状精度が許容值を満たすように, 前加工を行う際には図 6 に示寸ポリシング量分が除去されることを考慮す べきである。

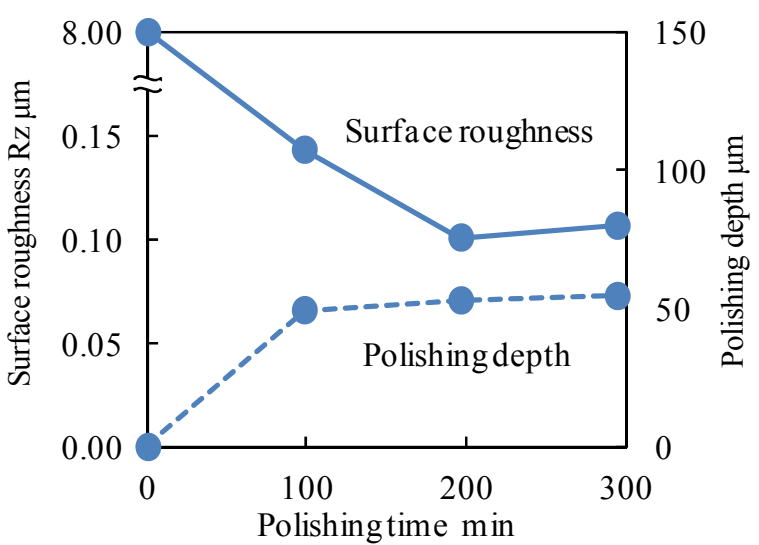

(a) Point tool

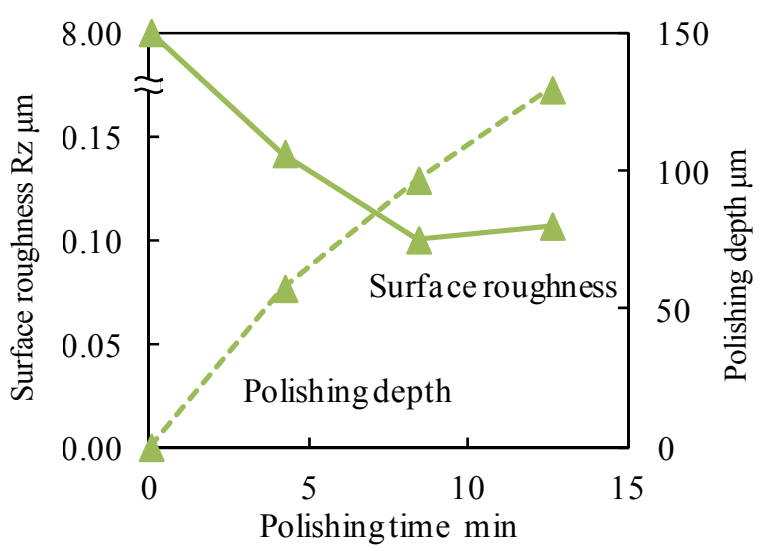

(c) Area tool (Rotational)

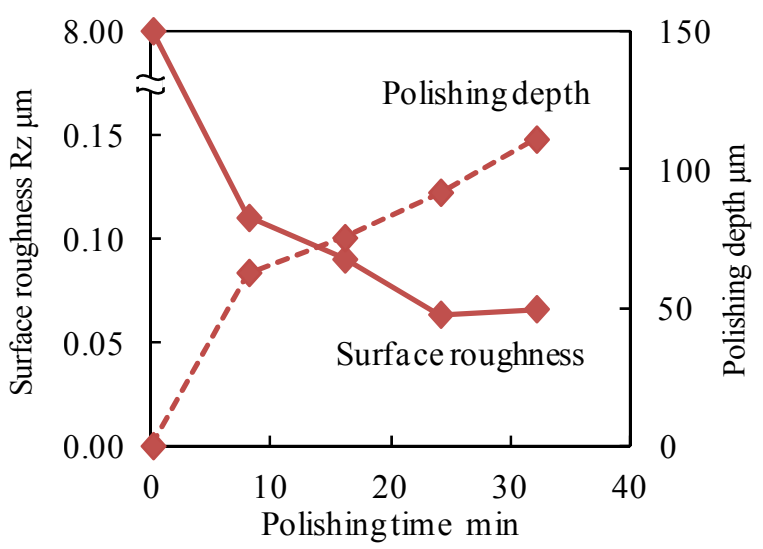

(b) Line tool

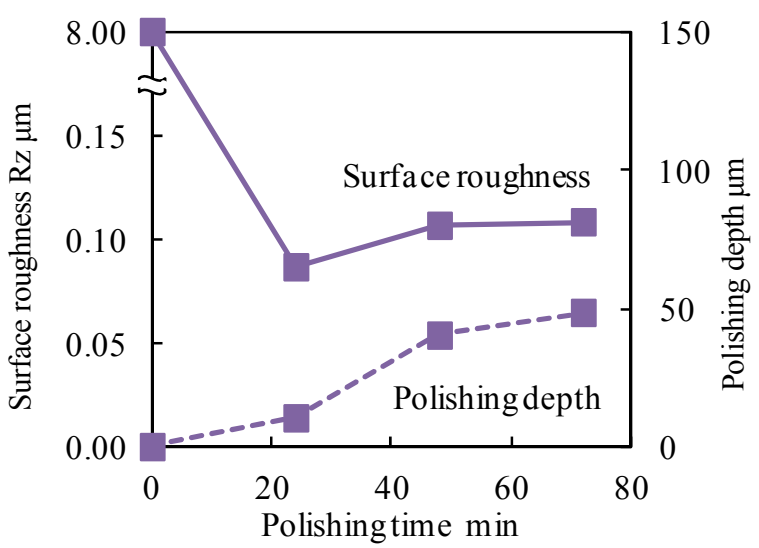

(d) Area tool (Irrotational)

Fig. 6 Relationship between polishing time and surface roughness or polishing depth 


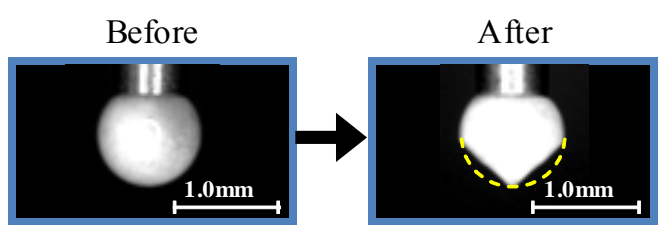

(a) Point tool

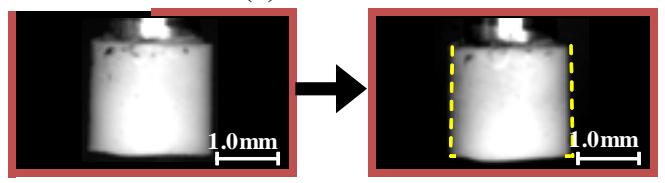

(b) Line tool

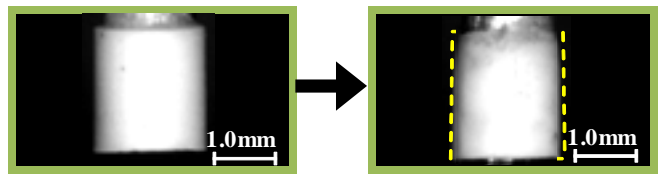

(c) Area tool (Rotational)

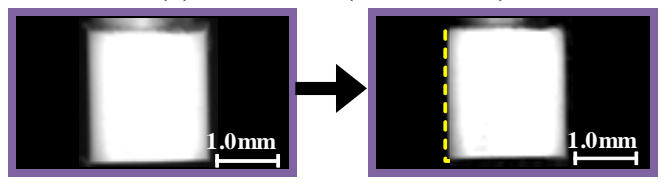

(d) Area tool (Irrotational)
Volume change

Volume before polishing - Volume after polishing

Volume before polishing

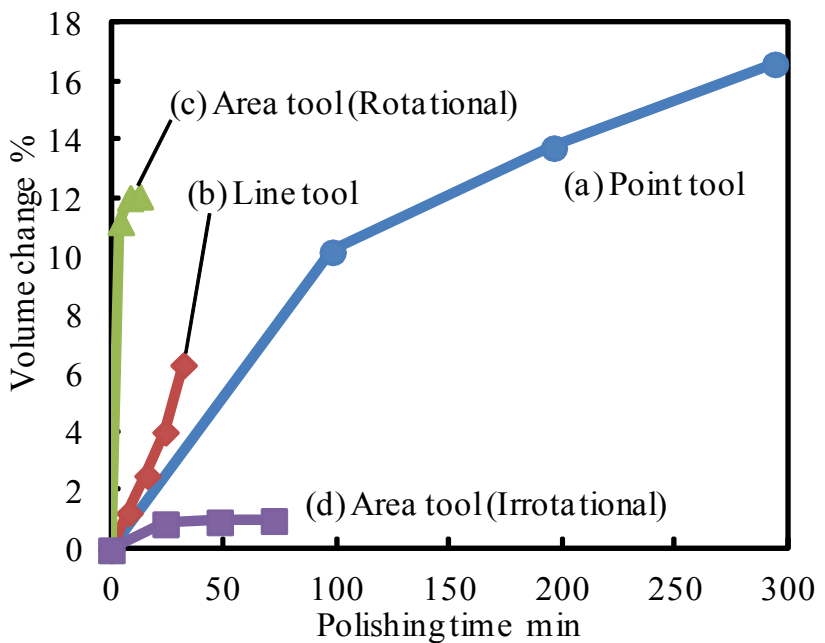

Fig. 7 Relationship between polishing time and volume change of the polishing head

\section{4. 複雑形状の微細金型を用いた高効率ポリシング加工技術の評価}

図 8 に, 本手法の有効性を評価するために用意した, 複雑形状を有する微細金型の図面を示す. 材質は超硬 V10 で，前加工の型彫り放電加工を行った段階での表面粗さ（最大高さ）は Rz $8.0 \mu \mathrm{m}$ であった．加工部分は底面， バンク面, 側面の 3 箇所に大別でき，平面部だけでなく円錐面を有しているのが特徵である. $1 \mathrm{~mm}$ 以下の仕上げ 寸法が複数あり, 寸法精度は $\pm 10 \mu \mathrm{m} \sim \pm 20 \mu \mathrm{m}$ に設定されている. このような複雑形状を有する微細金型は, 従 来のポリシング加工技術(3)では対応が困難であった.

表 4 に，本評価実験での加工条件を示す．前章までの考察をもとに最適条件を設定している．最適なポリシン グ工具の選定として, $3 \cdot 1$ 節の各ポリシング工具の選択および表 3 のポリシング性能を考慮し, 底面とバンク面 には面ポリシング工具を，側面には線ポリシング工具を使用することにした．また，加工時間を比較するため， 複雑形状のポリシング加工を得意とする点ポリシング工具のみでの加工も行った．加工には CNC ジグボーラを 使用し，NC 制御による自動ポリシング加工を行った。

図 9 にマイクロスコープで撮影した金型の加工前後での写真をそれぞれ示す. 図 9(b)の点ポリシング工具では, 縁や各面間の境界において不均一な加工による反射の違いが見られるが，図 9(c)の最適工具の組み合わせでは均 一に加工できている．この結果より，金型の表面性状は向上し，高品位化が可能になったと言える.

図 10 に金型の各箇所における表面粗さを示寸. 表面粗さ測定はポリシング加工方向とは垂直に行った. 加工前 の表面粗さ（最大高さ粗さ $\mathrm{Rz} ） 8.0 \mu \mathrm{m}$ が，加工後には $0.1 \mu \mathrm{m} \sim 0.2 \mu \mathrm{m}$ に改善しており, 本自動ポリシング加工 によって複雑形状の微細金型を鏡面に近い状態にまで加工することができた.

図 11 に加工箇所別の加工時間を示す. 点ポリシング工具のみを使用した場合は加工時間が 83 分必要であった のに対して，最適なポリシング工具の組合せを行うことで加工時間が 6 分（点ポリシング工具のみの場合の $1 / 10$ 以下. この值は部品形状に依存し, 点・線・面の各ポリシング工具の使用比率で大きく変化する. また, 部品材 質が変わった場合には, 最適加工条件が上記 3 種類の工具ごとに変化するので間接的にこの值に影響する.）に短 縮できた．以上の結果より，本自動ポリシング加工はきわめて有効な加工技術として評価することができる.

なお，今回は超硬 V10 を工作物としたが，SKD材，ステンレス鋼，黄銅，プラスチック ${ }^{(5)}$ な゙軟質材でも同様 のポリシング加工が可能である. また, 本報で工具のマトリックス材として使用したエポキシ樹脂は, その硬度 や強度などの機械的特性に温度依存性 ${ }^{(11)}$ があるため, 現象を把握し温度管理を十分に考慮する必要がある. この エポキシ樹脂の温度依存性に関しては, 今後の研究課題とする. 


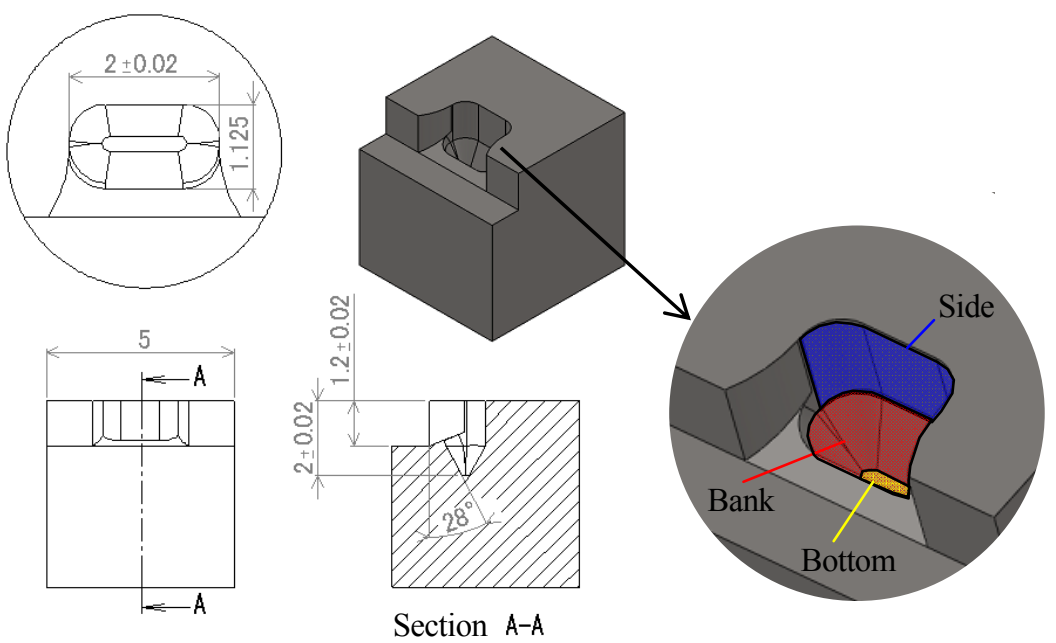

Fig. 8 Schematic view of the small die with complex shape

Table 4 Polishing condition for the small die with complex shape

\begin{tabular}{|c|c|c|c|}
\hline & \multirow{2}{*}{ Point tool } & \multicolumn{2}{|c|}{ Optimum combination tools } \\
\hline & & Side & Bank and Bottom \\
\hline Shape of the tools & \begin{tabular}{l|ll}
$i$ & Shaft $\phi 0.7$ \\
$\vdots$ & & \\
Ball $\phi 0.9$
\end{tabular} & $\begin{array}{l}\text { Shaft } \phi 0.7 \\
\phi 1.125 \\
\frac{\infty}{\varnothing \uparrow} \\
\varnothing 0.275\end{array}$ & 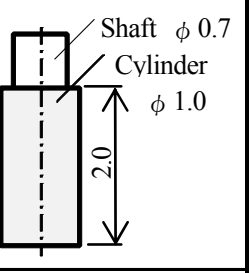 \\
\hline Spindle speed & 10000 & 10000 & 10000 \\
\hline Feed speed $\quad \mathrm{mm} / \mathrm{min}$ & 2.0 & 0.5 & 2.0 \\
\hline Polishing pressure $\mathrm{MPa}$ & 80 & 3 & 50 \\
\hline Number of process & 2.5 & 1.0 & 2.5 \\
\hline Workpiece & \multicolumn{3}{|c|}{ Carbide (V10), Surface roughness Rz $8 \mu \mathrm{m}$} \\
\hline
\end{tabular}

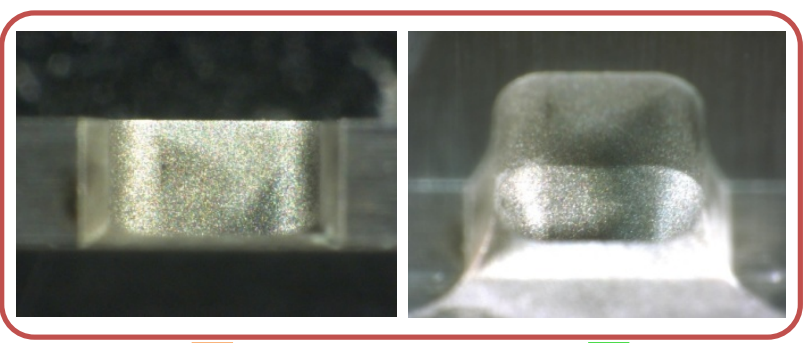

Polishing time: $83 \mathrm{~min}$

(a) Before polishing

Polishing time: $6 \mathrm{~min}$

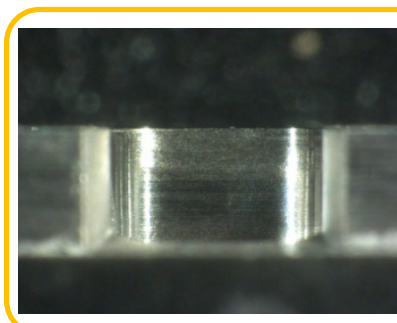

(b) After polishing using the point tool only

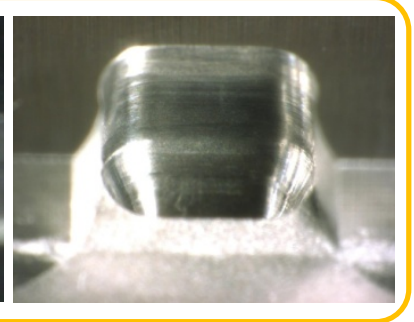

Fig. 9 Photographs before and after polishing

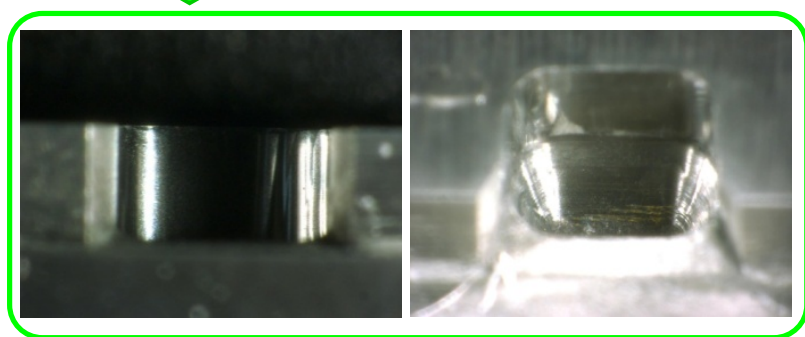

(c) After polishing using optimum combination tools 


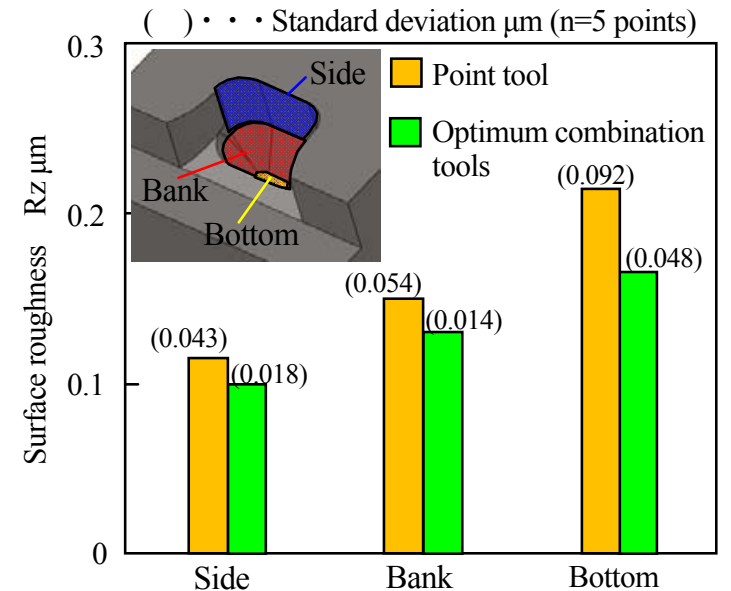

Fig.10 Surface roughness of complex shaped small die ( Surface roughness before polishing: Rz $8 \mu \mathrm{m}$ )

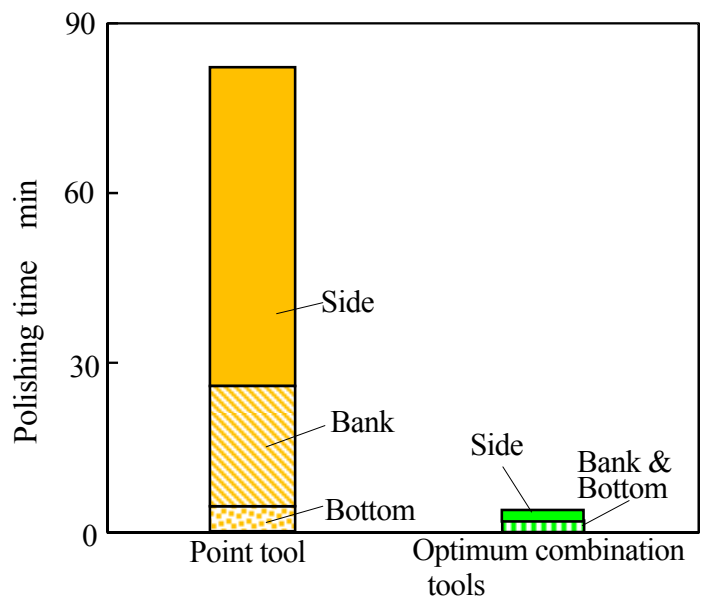

Fig.11 Relationship between used tools and polishing time

\section{5. 結言}

本報では，複雑形状の微細部品を効率良く鏡面加工するために，ポリシング工具とその加工技術を開発し，そ れを使用して微細金型の鏡面加工を行い，その有効性を評価した，その結果をまとめると以下のとおりである.

（1）開発した 4 種類のポリシング工具で, 図 8 の微細金型 (加工部 $2.0 \times 1.125 \times 2.0 \mathrm{~mm}$ に垂直平面, 傾斜平面, 円筒面，円錐面，底部と傾斜平面・円錐面の角付）に対して, 表面粗さ $\mathrm{Rz}=0.17 \mu \mathrm{m}$ (標準偏差 0.048 ) 以 下の加工が可能であった.

（2）開発した 4 種類のポリシング工具で, 図 8 の微細部品の鏡面加工を $\mathrm{NC}$ 制御のみで自動で加工できた.

（3）図 8 の微細部品（超硬V10）に関して, 点ポリシング工具のみで加工を行った場合と比べて, 開発し た 4 種類のポリシング工具を組み合わせることで加工時間を $1 / 10$ 以下に短縮でき，微細金型の高効率 な鏡面加工が可能になった.

\section{文献}

(1) 佐々木哲夫, 三好隆志, 斎藤勝政, 加藤木修，“金型磨き作業の知識獲得と自動化に関する研究（第 1 報, 金型熟練工 の手磨き特性）”，精密工学会誌，Vol. 57, No. 3 (1991), pp.497-502.

(2) 田辺郁男, 井山徹郎, Aung Lwin Moe, 近藤龍一，“大型金型の高速ポリシング加工”，日本機械学会論文集 C 編, Vol. 76, No. 772 ( 2010 ), pp.3822-3827.

(3) 田辺郁男, 近藤大透, 井上大和, 井山徹郎, “リニアモータ駆動を用いた高速微細ポリシング加工” , 日本機械学 会論文集 C 編, Vol. 77, No. 779 ( 2011 ), pp.2855-2861.

(4) 井山徹郎, 田辺郁男, “熱軟化による硬度管理加工な研磨工具を用いた軟質材料の鏡面加工” , 日本機械学会論文 集 C 編, Vol. 77, No. 775 ( 2011 ), pp.1154-1160.

(5) 田辺郁男, 井上大和, 井山徹郎, “複雑形状の微細金型ポリシング加工技術の開発”, 日本機械学会論文集 C 編, Vol. 78, No.791 (2012), pp.313-322.

(6) 池野順一, 谷泰弘, “電気泳動現象を利用した超微粒砥石の作成に関寸る研究”, 生産研究, 42 巻, 6 号 (1990), pp.385-388.

(7) 不破徳人，池野順一，渋谷秀雄，堀内 宰，“水晶の鏡面研削に関する研究（EPD 砥石の試作とその研削特性につ いて)”, 砥粒加工学会誌, Vol. 52, No.6 (2008), pp.333-338.

（8）梅原徳次，萩原晋作，柴田 勲，枝村一弥，“MAGIC 砥石の開発とその応用（第 1 報, 磁場配列を利用した新しい 砥石による研磨の原理と基本特性”, 砥粒加工学会誌, Vol. 45, No.9 (2001), pp.431-436.

(9) 井山徹郎, 田辺郁男, 高橋 勉, “超硬金型の自動ラッピングシステムにおけるラップ剂の最適化とその評価”, 日 本機械学会論文集 C 編, Vol. 75, No. 749 (2009), pp.210-215.

(10) 田辺郁男,井山徹郎,柳澤賢寿, 水谷淳之介, “試作レスC A E システムの開発（誤差因子の分散を考慮したシス テムの高精度化）”，日本機械学会論文集 C 編, Vol. 75, No. 749 (2009), pp. 203-209.

(11) 笠森正人, 大塚 猛, 新保 實, 宮野 靖, “耐熱エポキシ樹脂およびその CFRP 積層板の材料特性の時間一温度 依存性”，材料, Vol. 41, No.463 (1992), pp.465-469. 